\title{
MODEL MULTI SITUS DI CABANG MUHAMMADIYAH KARTASURA UNTUK EFISIENSI PENGELOLAAN WEB BERBAGAI AMAL USAHA
}

\author{
Husni Thamrin dan Albert Septiawan \\ Program Studi Informatika \\ Fakultas Komunikasi dan Informatika \\ Universitas Muhammadiyah Surakarta \\ Email: husni.thamrin@ums.ac.id
}

\begin{abstract}
ABSTRAK
Muhammadiyah adalah salah satu organisasi Islam terbesar di Indonesia dengan jumlah ribuan cabang di seluruh Indonesia. Dakwah Muhammadiyah tidak hanya berbentuk ceramah melainkan juga memberikan pelayanan sosial dalam bentuk panti asuhan, sekolah, pesantren, dan rumah sakit. Keberadaan dan aktivitas amal usaha Muhammadiyah, khususnya di cabang Kartasura belum cukup dikenal masyarakat karena minimnya sarana dalam mensosialisasikan. Teknologi internet merupakan solusi untuk pengenalan AUM ke masyarakat namun, terdapat kendala operasional dalam baik biaya maupun sumber daya manusia. Kendala tersebut dapat diatasi dengan penerapan model multi situs dengan satu situs induk untuk pimpinan cabang Kartasura dan sub situs untuk seluruh AUM yang belum memiliki situs. Implementasi model telah dilakukan dan pelatihan bagi pengelola situs dan sub situs telah dilaksanakan. Implementasi model multi situs terbukti lebih efisien dalam hal biaya hingga $84 \%$. Efisiensi dalam jumlah personil pengelola diperoleh karena implementasi model multi situs di cabang Kartasura dapat dikelola hanya oleh 3 orang untuk lebih dari 10 situs.
\end{abstract}

Keywords: situs web, model multi situs, amal usaha muhammadiyah, cabang Muhammadiyah

\section{PENDAHULUAN}

Muhammadiyah termasuk salah satu organisasi islam terbesar di Indonesia (Azra et al., 2009). Muhammadiyah memiliki tatanan organisasi yang sangat terstruktur dari pusat hingga ranting, sehingga seluruh unsur dapat bergerak menjalankan roda organisasi untuk mencapai tujuannya, yakni menegakkan dan menjunjung tinggi agama Islam sehingga terwujud masyarakat Islam yang sebenar-benarnya. Dakwah yang dilakukan muhammadiyah tidak hanya dilakukan melalui ceramah di majelis taklim atau masjid, tetapi juga melalui kegiatan nyata di masyarakat dalam berbagai bentuk, seperti rumah sakit, sekolah, pesantren, dan panti asuhan. Bentuk kegiatan nyata itu disebut Amal Usaha Muhammadiyah (AUM). AUM bergerak di berbagai bidang seperti pendidikan, sosial, ekonomi, dan layanan kesehatan.

Cabang Muhammadiyah adalah satu kesatuan dari organisasi yang bergerak di tingkat cabang (umumnya berada di area kecamatan) serta melaksanakan kebijakan pimpinan di atasnya yakni dari tingkat pusat hingga daerah (Pimpinan Pusat Muhammadiyah, 2010). Salah satu tugas cabang Muhammadiyah adalah mengkoordinasikan kegiatan AUM yang dinaunginya, di samping tugas utama melaksanakan dakwah di area cabang tersebut. Sebuah cabang dapat menaungi beberapa jenis amal usaha meliputi sekolah dasar, sekolah menengah, klinik dan rumah sakit, baitul mal, panti asuhan, dan masjid. Jenis dan jumlah amal usaha yang dikelola bervariasi di antara satu cabang dengan 
cabang lainnya tergantung lokasi dan kebutuhan masyarakat.

Salah satu cabang Muhammadiyah yang berjalan cukup baik adalah Cabang Kartasura yang terletak di Kecamatan Kartasura, Kabupaten Sukoharjo, Jawa Tengah. Muhammadiyah cabang Kartasura memiliki belasan amal usaha. Amal usaha yang menonjol berada di bawah koordinasi Pimpinan Cabang Kartasura adalah sekolah, rumah sakit, dan masjid. Jumlahnya puluhan. Tiap amal usaha memiliki aktivitas dan fasilitas yang bermacam-macam, dan memberikan layanan kepada umat secara berbeda dalam hal kualitas dan sasaran. Namun sayang, informasi tentang keberadaan amal usaha, kegiatan, fasilitas, dan layanan tidak mudah diperoleh oleh masyarakat luas. Pimpinan cabang belum memiliki situs web untuk menyebarluaskan informasi, begitu pula kebanyakan amal usaha. Sebagian telah memiliki akun media sosial, namun tidak semuanya menyajikan informasi yang upto-date. Kendala yang dihadapi adalah tidak semua amal usaha memiliki kemampuan untuk memiliki dan mengelola situs web (Kuswaji, komunikasi personal, 17 Januari 2017).

Situs web memberi banyak manfaat bagi sebuah lembaga. Situs web merupakan media komunikasi yang informasinya tidak akan pernah terbuang menjadi sampah, dan selalu tersedia di sepanjang waktu. Informasi tersebut dapat diakses dari berbagai tempat, dari rumah, kantor, bahkan di dalam perjalanan melalui smartphone. Informasi di web dapat di-update dengan mudah. Situs web sangat murah, dibanding media komunikasi yang lain seperti leaflet, telpon, buletin atau majalah. Kesungguhan mengelola situs web akan menunjukkan komitmen lembaga dalam memberikan layanan kepada masyarakat atau pelanggan. Selain itu, situs web dapat meningkatkan legitimasi lembaga karena masyarakat dapat mengkonfirmasi keberadaan lembaga melalui internet (Barack, 2014). Penetrasi internet yang tinggi menjadi jalan bagi masyarakat untuk mencari dan menemukan informasi terkait lembaga melalui jejaring global tersebut. Berdasarkan sebuah laporan statistik, (http://www.internetlivestats.com, 2017), selama tahun 2016 Indonesia berada dalam peringkat 12 dari 201 negara untuk pengguna internet aktif.

Situs web digunakan untuk berbagai keperluan, misalnya sebagai alat koordinasi (Budhirianto, 2014), peningkatan citra instansi seperti sekolah (Khusnia \& Riasti, 2014), sarana untuk melakukan survei penelitian (Thamrin \& Sabardila, 2016), publikasi jadwal dokter untuk menginformasikan pasien yang akan berobat pada rumah sakit (Rosyadi \& Rohmadi, 2013), serta pemberitahuan pengumuman ataupun berita darurat seperti informasi daerah bencana (Majchrzak \& More, 2011).

Ada tiga biaya yang diperlukan untuk memulai situs web. Ketiga biaya itu adalah biaya pengembangan sistem, membeli domain, dan menyewa server (hosting). Selain ketiga biaya itu, terdapat biaya untuk memelihara situs, termasuk biaya operasional dan biaya menambah dan meng-update konten. Di antara kelima biaya tersebut, biaya pengembangan sangat bervariasi tergantung desain dan komponen yang dipakai dalam situs (Chank, 2014).

Untuk menghemat biaya, beberapa lembaga yang berada dalam naungan sebuah organisasi atau konsorsium dapat mengembangkan multi situs, atau sebuah situs dengan sub situs. Tulisan ini mendeskripsikan penerapan model multi situs bagi Cabang Muhammadiyah Kartasura beserta AUM yang berada di bawah koordinasinya. Informasi untuk seluruh situs tersimpan secara integratif pada sebuah database. Seorang admin dirancang untuk memiliki hak kendali penuh terhadap seluruh situs web. Sedangkan sub situs dikendalikan oleh seorang staf (admin bagi sub situs), yang dapat mengatur berbagai segi dari sub situs termasuk menu dan konten.

\section{METODE PELAKSANAAN}

Penerapan model multi situs dilakukan melalui tiga tahap yaitu pengembangan situs 
web, pelatihan bagi administrator situs, dan pelatihan bagi pengguna. Pengembangan situs dilakukan menggunakan metode waterfall. Metode waterfall terdiri atas tujuh tahap yakni analisis kebutuhan (requirement analysis), perancangan (design), pembangunan (development), pengujian (testing), penerapan di lingkungan nyata (implementation), dan perawatan (maintenance). Metode waterfall dipilih karena kebutuhan sistem sudah jelas di awal pengembangan, kemungkinan perubahan kebutuhan sangat kecil, dan hanya dibutuhkan sumber daya yang kecil dalam implementasi metode (Balaji \& Murugaiyan, 2012).

\section{Analisis Kebutuhan}

Pada tahap analisis kebutuhan, dilakukan pengumpulan informasi dalam bentuk observasi dan wawancara. Observasi dilakukan dengan mencermati situs web yang ada, baik yang dimiliki oleh Pimpinan Pusat Muhammadiyah maupun yang telah dimiliki oleh beberapa AUM di Kartasura. Selain itu dilakukan pula pengamatan terhadap akun media sosial. Observasi diperlukan untuk melihat konten yang selama ini disebarluaskan melalui internet ke masyarakat. Wawancara dilakukan kepada pimpinan cabang dengan mengajukan pertanyaan mengenai kebutuhan konten dan tampilan web.

\section{Perancangan}

Tahap perancangan (design) dilakukan dengan membuat rancangan usecase diagram, activity diagram, dan class diagram. Berdasarkan analisis kebutuhan, diperlukan situs web untuk cabang sebagai pusat informasi bagi masyarakat untuk mengakses informasi kegiatan, galeri, berkas seperti panduan surat, prosedur, putusan tarjih dan sebagainya. Situs web diarahkan untuk menampilkan informasi spesifik terkait masing-masing AUM seperti informasi penerimaan siswa baru, alamat, prestasi, kontak yang dapat dihubungi dari suatu sekolah muhammadiyah, daftar peralatan yang tersedia, jadwal praktek dokter harian, serta petunjuk teknis lainnya dari Rumah Sakit PKU.
Situs web menyediakan fitur bagi kontributor yang ingin berbagi tulisan ataupun berita kepada salah satu sub situs. Tulisan atau berita dari kontributor akan dicek oleh staff sub situs untuk memastikan bahwa isi konten layak terbit. Selain itu, diperlukan fitur penyebaran artikel informasi (broadcast atau direct post) dari pengelola di tingkat cabang ke seluruh sub situs.

\section{a. Use sase diagram}

Situs web yang dikembangkan dapat diakses oleh empat jenis aktor yaitu admin, staff, kontributor, dan masyarakat. Use case diagram pada Gambar 1 memperlihatkan peran dan aktivitas yang dapat dilakukan setiap aktor. Staff bertanggung jawab terhadap semua konten pada masing-masing sub situs (situs untuk masing-masing AUM), termasuk mengubah menu dan profil. Admin bertanggung jawab atas pengelolaan user, pembuatan sub situs baru, penghapusan sub situs, dan melakukan manajemen situs induk (yaitu situs untuk cabang Kartasura). Kontributor dapat mengirim artikel dan berita untuk sub situs tertentu, namun artikel tersebut harus mendapat persetujuan staff sebelum terpublikasi di web. Selain ketiga aktor tersebut, setiap pengunjung situs dapat membaca seluruh informasi yang sudah dipublikasikan.

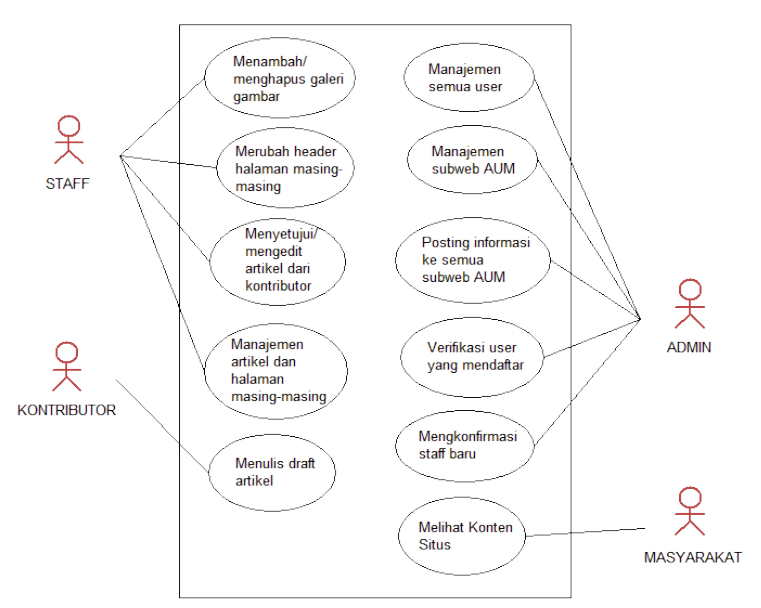

Gambar 1. Use Case Diagram Admin, Staff dan Kontributor

\section{b. Activity Diagram}

Diagram aktivitas (activity diagram) menggambarkan detil apa yang dilakukan 
pengguna, sistem atau komponen sistem pada saat sebuah aktivitas berjalan. Seluruh aktivitas yang ada pada use case diagram (Gambar 1) didetilkan ke dalam sebuah diagram aktivitas. Contoh diagram aktivitas dapat dilihat pada Gambar 2 yang memperlihatkan langkah-langkah yang dilalui pada pembuatan draft artikel oleh kontributor sampai verifikasi oleh staff terkait. c. Class Diagram

Diagram kelas (class diagram) menggambarkan entitas/objek berikut keterkaitan antar entitas. Pada diagram terdapat deskripsi tentang data yang tersimpan di objek dan dan perilaku objek di dalam aplikasi. Secara lengkap, diagram kelas untuk sistem multi situs yang dikembangkan dapat dilihat pada Gambar 3.

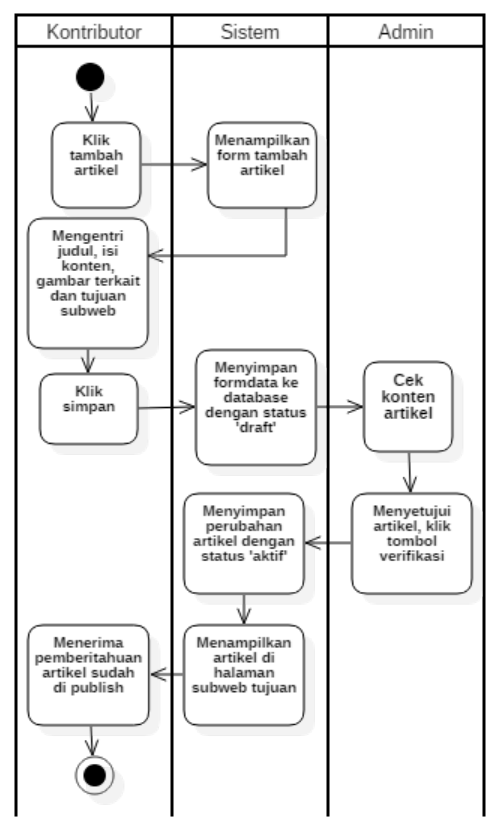

Gambar 2. Activity Diagram menambah kontribusi artikel

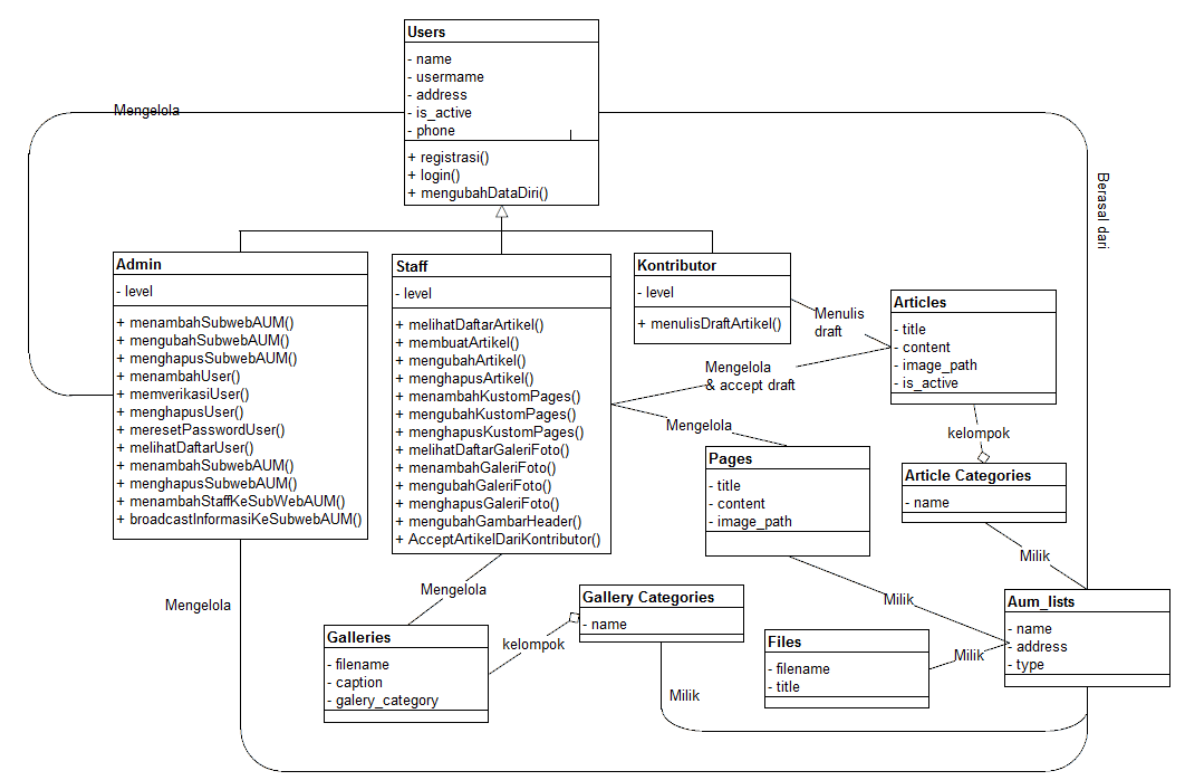

Gambar 3. Class Diagram Situs Web 
d. Rancangan Tampilan

Rancangan tampilan memperlihatkan tata letak komponen tampilan situs, seperti posisi banner, posisi menu, dan posisi artikel

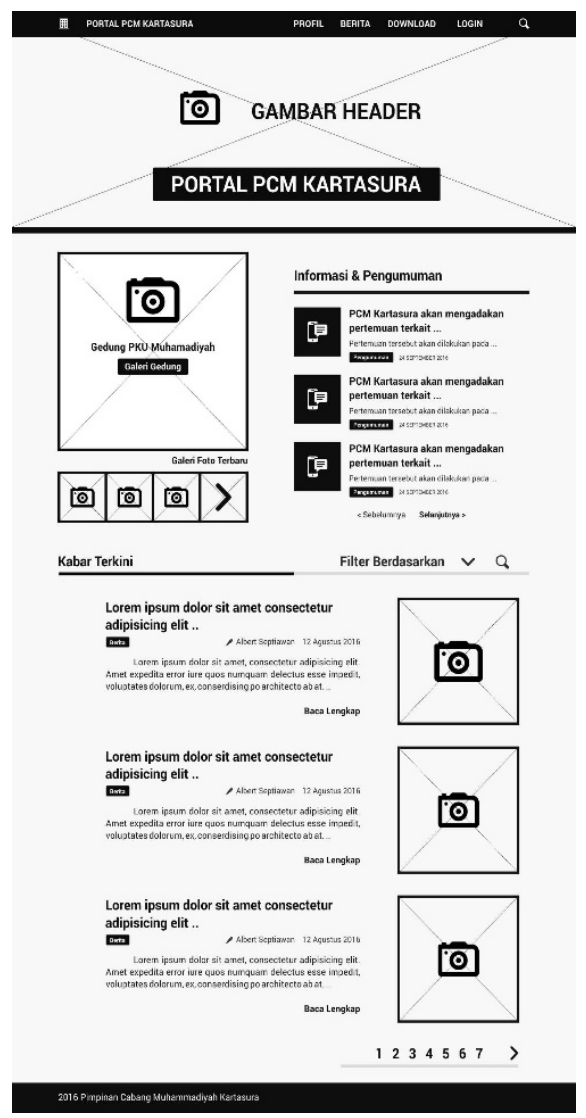

Gambar 4. Rancangan tampilan situs induk Cabang Muhammadiyah Kartasura

\section{Pengembangan}

Pembuatan

sistem yang mengimplementasikan model multi situs menggunakan bahasa pemrograman PHP dan basis data menggunakan MySQL. Beberapa komponen penting telah diterapkan pada sistem ini seperti mobile responsive view untuk menunjang tampilan yang responsif, tampilan peta dari Google Map, dan komponen dari Laravel PHP Framework.

\section{Pengujian}

Pengujian sistem dari situs web terintegrasi ini menggunakan metode black box yang lebih terfokus pada pengujian fungsionalitas (Kumar, Singh, \& Dwivedi, 2015). Pengujian melibatkan pihak cabang Muhammadiyah Kartasura sebagai operator utama dalam situs untuk mengetahui lebih berita. Rancangan tampilan untuk situs induk dan sub situs dapat dilihat pada Gambar 4 dan Gambar 5.

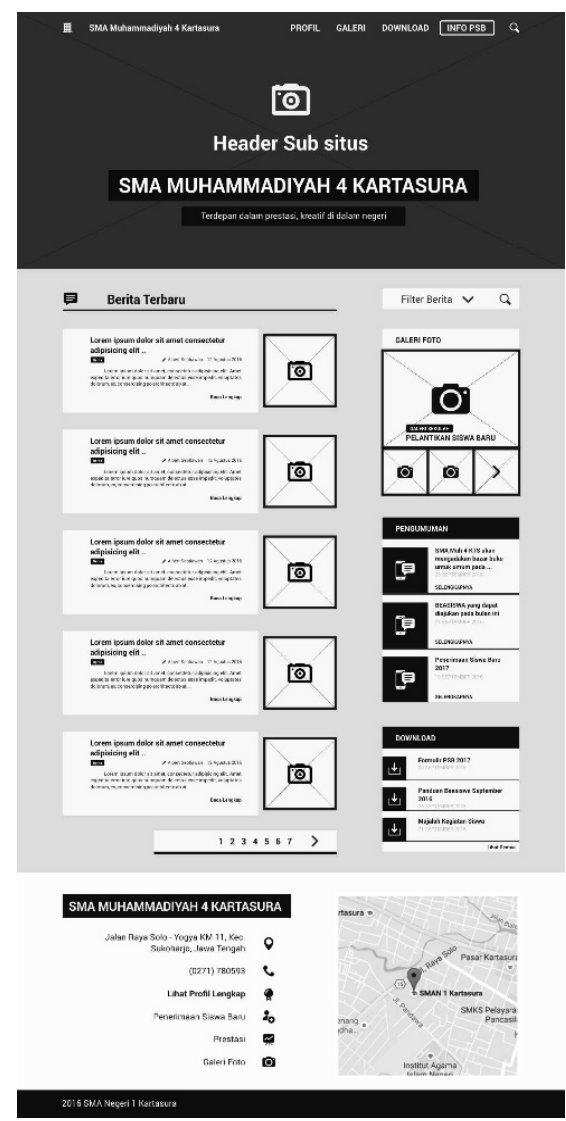

Gambar 5. Rancangan tampilan sub situs AUM

dalam potensi kesalahan yang disebabkan oleh pengguna dalam mengoperasikan situs web.

\section{Implementasi}

Implementasi situs web di lingkungan nyata dilakukan dengan menyewa dari sebuah web hosting. Fitur yang dipilih adalah kapasitas penyimpanan tidak terbatas (unlimited), karena dimungkinkan terdapat banyak berkas untuk publikasi dan gambar milik masing-masing sub situs. Alamat URL dari situs induk adalah http://www. pcmkartasura.or.id sedang alamat URL masing-masing sub situs memiliki pola http:// www.pcmkartasura.or.id/a/nama-sub-situs.

\section{Perawatan}

Perawatan operasional dilakukan oleh Pimpian Cabang Muhammadiyah Kartasura 
bekerja sama dengan Pimpinan Cabang Pemuda Muhammadiyah (PCPM) Kartasura. Perawatan teknis dapat dilakukan oleh dengan bantuan dari pengembang awal atau pengembang lain di bawah kendali PCPM Kartasura.

\section{HASIL DAN PEMBAHASAN}

\section{Pengembangan dan Pengujian}

Proses pengembangan sistem telah menghasilkan model multi situs yang terdiri atas dua jenis situs. Pertama adalah situs induk untuk cabang Muhammadiyah Kartasura, dan kedua adalah sub situs untuk AUM dan lembaga di bawah cabang Muhammadiyah Kartasura. Setiap situs dilengkapi komponen peta dari Google Map untuk menampilkan dengan akurat lokasi dari cabang atau amal usaha yang dideskripsikan

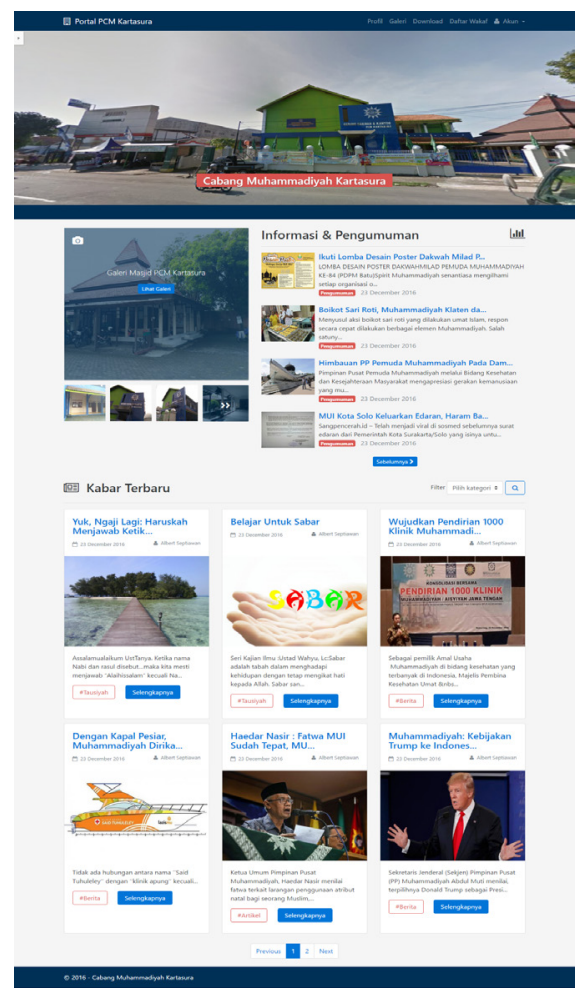

Gambar 6. Halaman awal situs induk

Halaman manajemen untuk admin memungkinkan akses untuk manajemen semua pengguna dan semua sub situs. Aktivitas menambah data pengguna, menghapus, memperbarui data asal instansi, me-reset password, dan verifikasi pengguna baru hanya bisa dilakukan oleh admin. pada situs. Halaman utama dari situs induk (Gambar 6) dan sub situs (Gambar 7) masingmasing memiliki menu navigasi untuk menuju ke artikel, pengumuman, galeri, halaman tertentu, download, login pengelola, serta menu lain sesuai dengan pengaturan pengelola. Semua halaman pada tiap situs dilengkapi dengan thumbnail gambar (gambar berukuran lebih kecil dari gambar asli). Web menerapkan teknologi $A J A X$ (Asynchronous Javascript and XML) untuk meminimalkan ukuran data yang ditransfer dari server sehingga proses penampilan halaman web menjadi lebih cepat. Library dari framework bootstrap4 yang digunakan juga membuat semua halaman situs menjadi responsif yakni, semua konten dapat terbaca dengan baik di layar komputer ataupun perangkat berukuran layar lebih kecil.

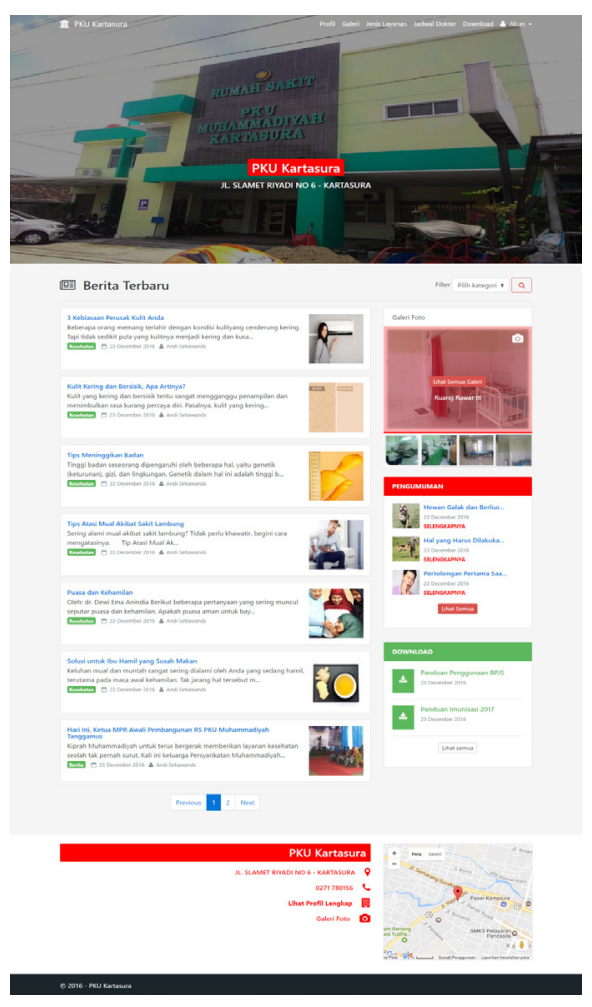

Gambar 7. Halaman awal sub situs

Pengelolaan sub situs meliputi menambahkan dan menghapus juga hanya dapat dilakukan oleh pengguna dengan level admin. Admin diberi wewenang untuk mengelola situs induk seperti manajemen pengumuman, manajemen artikel, melakukan proses broadcast (memungkinkan artikel dari 
situs induk terbaca di semua subsitus), menambahkan halaman kustom, mengelola galeri gambar, berkas, dan menu yang dapat disesuaikan dengan kebutuhan.

Halaman manajemen untuk staff memungkinkan akses untuk mengelola konten yang terkait dengan sub situs masing-masing. Akses yang dimaksud meliputi manajemen profil, pengumuman, artikel (termasuk verifikasi draft artikel dari kontributor), manajemen halaman kustom, galeri foto, berkas, serta menu navigasi. Pengguna level staff juga dapat memperbarui profil pribadinya dan memperbarui profil yang berkaitan dengan sub situs yang dikelolanya seperti alamat, kontak, dan koordinat lokasi dalam peta.

Pengujian sistem multi situs dilakukan dengan metode black box. Pengujian ini bertujuan untuk mengetahui apakah sistem berjalan baik atau tidak sesuai dengan fungsinya. Untuk itu pengujian ini difokuskan kepada pencarian kesalahan atau ketidaksesuaian pada interface, request data dari database, dan struktur data dalam sistem. Kelemahan sistem dapat diketahui dengan pengujian, sehingga saat ditemukan kelemahan, sistem dapat segera diperbaiki dan disempurnakan. Dengan kata lain, pengujian membantu meningkatkan kualitas sistem dalam situs web terintegrasi ini.

Pengujian telah dilakukan terhadap 8 aksi pada halaman utama situs induk, 8 aksi pada halaman utama sub situs, 3 aksi pada halaman login, 8 aksi pada halaman pengelolaan untuk staff, 11 aksi pada halaman pengelolaan untuk admin, dan 2 aksi pada halaman kontributor. Hasil pengujian menunjukkan bahwa semua aksi dapat berjalan dengan baik. Hasil pengujian mengkonfirmasi, bahwa model multi situs telah berhasil dibuat dan berjalan dengan baik secara fungsional dengan tidak ditemukan kesalahan. Tentu saja proses pengujian tidak hanya dilakukan satu kali karena setiap kali didapati kesalahan, dilakukan perbaikan pada sistem kemudian pengujian diulang kembali dari awal.

\section{Implementasi dan Pelatihan}

Situs web telah diimplementasikan dan dipasang (deploy) pada sebuah web hosting. Untuk mengoperasikan situs tersebut, diperlukan pelatihan baik untuk administrator, staff, maupun kontributor. Pelatihan dilakukan dalam dua tahap. Pelatihan untuk admin dilakukan pada tanggal 21 Jauari 2017 dengan melibatkan tiga anggota Pimpinan Cabang Pemuda Muhammadiyah (lihat Gambar 8). Untuk kebutuhan pelatihan dan pengoperasian telah disusun panduan pengelolaan situs yang dapat diunduh dari situs induk pemkartasura. or.id.

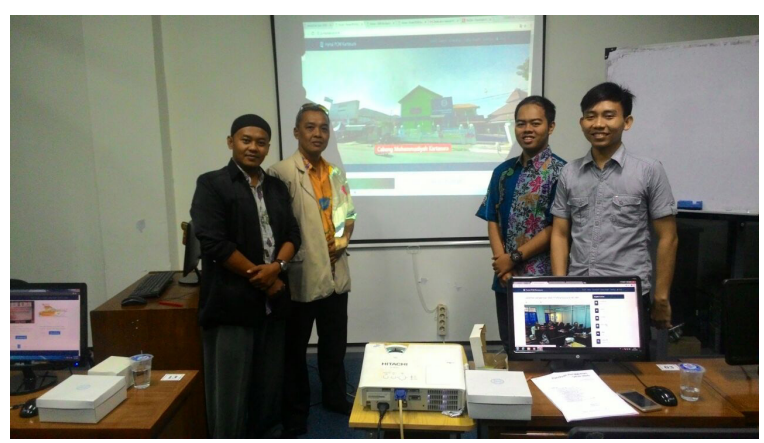

Gambar 8. Peserta pelatihan administrasi situs bersama salah satu penulis

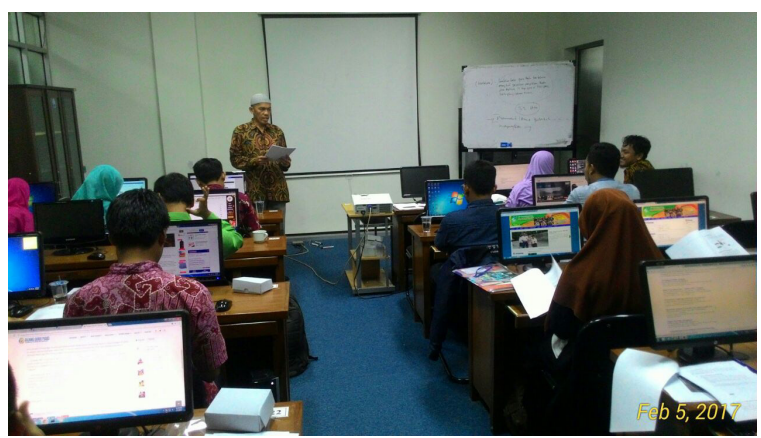

Gambar 9. Suasana pelatihan bagi staff dan kontributor

Pelatihan untuk staff dan kontributor dilakukan pada tanggal 5 Pebruari 2017. Pelatihan melibatkan tidak kurang dari 11 AUM yang masing-masing mengirimkan dua orang anggota (Gambar 9). Setiap wakil dari AUM diharapkan menjadi staf dan kontributor. Pelatihan tentang pengelolaan web dan sub situs dilakukan berbarengan dengan pelatihan lain dengan materi tentang penulisan jurnalistik dan berita. Hal ini dilakukan, agar peserta tidak hanya mengetahui pengelolaan web secara teknis, namun juga memiliki bekal untuk 
mengoperasionalkan masing-masing sub situs.

\section{Pembahasan}

Setiap situs web membutuhkan berbagai komponen sebelum dapat diakses melalui internet. Perangkat keras yang diperlukan adalah server yang menyimpan halaman web, dan disebut server web. Untuk kebanyakan situs dengan konten yang dinamis, diperlukan server untuk menyimpan data, yang sering dikenal dengan server basis data. Kedua jenis server dapat disatukan dalam sebuah perangkat keras dan dapat dibeli atau disewa. Selain server, diperlukan koneksi internet yang harus disewa dari penyedia jasa. Kebutuhan terakhir adalah alamat web sebagai penanda atau identitas dari web yang mudah diingat atau dikenal masyarakat. Alamat web harus didaftarkan ke pihak pengelola dan untuk itu diperlukan biaya administrasi.

Untuk mendapatkan biaya termurah, berbagai komponen tersebut dapat disewa. Biaya sewa untuk penempatan sebuah situs bervariasi tergantung layanan. Sebagai contoh, biaya sewa tahun 2017 pada niagahoster.co.id adalah sebesar Rp. 14.900 per bulan untuk paket situs web standar. Untuk kasus cabang Kartasura dengan satu situs induk, 11 situs untuk sekolah dan satu situs rumah sakit, diperlukan 13 paket situs dengan harga total 13 × 12 × Rp. 14.900 atau sama dengan Rp. 2.324.400 per tahun. Penerapan model multi situs menyebabkan terjadinya penghematan. Paket yang harus disewa tentunya berbeda, karena diperlukan fitur penyimpanan tak terbatas dengan biaya sewa Rp. 29.450 per bulan. Oleh karena itu, penerapan model multi situs membutuhkan biaya sewa hosting sebesar 12 x Rp. 29.450 atau sama dengan Rp. 353.400 per tahun. Efisiensi penggunaan model multi situs mencapai 84 persen untuk sewa server!
Selain sewa server, kebutuhan operasional situs memerlukan setidaknya seorang administrator. Admin bertugas melakukan perawatan situs, melakukan backup data, dan melakukan tugas manajemen situs lainnya. Pada sistem multi situs, seorang admin dapat melakukan keseluruhan proses dengan satu kali login pada satu sistem. Meskipun banyak situs yang harus dikelola, pekerjaan yang dilakukan pada pengelolaan multi situs relatif lebih sedikit dibanding jika harus mengelola situs individual satu per satu sehingga lebih efisien. Apalagi sistem multi situs hanya memiliki satu basis data sehingga lebih mudah dirawat dibanding merawat 13 basis data.

Sistem multi situs memungkinkan dilakukannya proses broadcast atau direct post. Fitur ini akan membuat artikel yang terpilih dari situs induk dapat ditampilkan secara penuh di semua sub situs setara dengan artikel asli dari sub situs tersebut. Dengan cara ini, penyebarluasan informasi kepada masyarakat akan semakin cepat tanpa harus me-repost informasi secara manual dari situs induk. Setiap halaman sub situs secara otomatis akan terasa ter-update.

\section{KESIMPULAN}

Penerapan model multi situs untuk situs web Cabang Muhammadiyah Kartasura dapat memberikan efisiensi dalam pengembangan dan operasional. Efisiensi biaya diperoleh karena untuk banyak situs hanya diperlukan satu kali biaya sewa hosting. Untuk kasus cabang Muhammadiyah Kartasura dengan 13 sub situs, efisiensi biaya mencapai $84 \%$. Efisiensi pengelolaan dicapai karena untuk kesuluruhan situs induk dan sub situs dapat dikelola oleh 3 orang admin. Perawatan sistem juga lebih mudah karena keseluruhan data dan informasi di semua sub situs tersimpan dalam satu database.

\section{DAFTAR PUSTAKA}

Azra, A., Sukandar, R., Basya, M. H., Assyaukanie, L., Mu’ti, A., Ghazali, A. R., \& Setiadji, B. (2009). 100 Tahun Muhammadiyah: Civil Society dan Tantangan Gerakan Islam Transnasional. Maarif, 4(2), 1-94. 
p ISSN: 1410-9344, e ISSN: 2549-5631

Balaji, S., \& Murugaiyan, M. S. (2012). Waterfall Vs V-Model Vs Agile : A Comparative Study on SDLC. International Journal of Information Technology and Business Management, 2(1), 26-30.

Barack, T. (2014). 5 reasons your local NGO needs a website, http://www.tools4dev.org/ resources/ 5-reasons-your-local-ngo-needs-a-website/

Budhirianto, S. (2014). Pengembangan Jabar Cyber Province sebagai Media Informasi dan Komunikasi. Jurnal Penelitian Komunikasi, 17(1), 55-68.

Chank, H.E. (2014). Basic Website Components and Cost, http://nmstrategies.com

Khusnia, D., \& Riasti, B. K. (2014). Pembuatan Website Profil Sekolah Menengah Pertama Negeri 1 Kalitidu Bojonegoro. IJNS - Indonesian Journal on Networking and Security, $3(1), 1-6$.

Kumar, M., Singh, S. K., \& Dwivedi, R. K. (2015). A Comparative Study of Black Box Testing and White Box Testing Techniques. International Journal of Advance Research in Computer Science and Management Studies, 3(10), 32-44.

Majchrzak, A. N. N., \& More, P. H. B. (2011). Emergency! Web 2.0 to the Rescue!. Communications of the ACM, 54(4), 125-132.

Pimpinan Pusat Muhammadiyah. (2010). Anggaran Dasar dan Anggaran Rumah Tangga Muhammadiyah 2005. Yogyakarta: Surya Sarana Grafika.

Rosyadi, S. L., \& Rohmadi. (2013). Perancangan Website Rumah Sakit Assalam Gemolong Berbasis PHP. Seminar Riset Unggulan Nasional Informatika dan Komputer, 2(1), 69-76.

Sumarsono, \& Husin, A. S. (2013). Sistem Terintegrasi Portal Web Perguruan Tinggi Agama Islam Negeri Menggunakan Metode Grabbing. Kaunia, IX(2), 21-26.

Thamrin, H. \& Sabardila, A. (2016). Utilizing Lexical Relationship in Term-Based Similarity Measure to Improve Indonesian Short Text Classification. ARPN Journal of Engineering and Applied Sciences, 11(22), 13141-13145. 